\title{
A PRELIMINARY INVESTIGATION ON MICROSTRUCTURE AND MECHANICAL PROPERTIES OF DISSIMILAR AI TO Cu FRICTION STIR WELDS PREPARED USING SILVER INTERLAYER
}

\author{
Shailesh Pandya*, Jyoti Menghani \\ Mechanical Engineering Department, \\ S. V. National Institute of Technology, Surat, India
}

Received 17.06.2017

Accepted 14.03.2018

\begin{abstract}
Due to its solid-state nature, friction stir welding (FSW) process can be considered a better alternative for dissimilar welding metals. However, like fusion welding techniques, in friction stir welding growth of thick layers of brittle intermetallics - $\mathrm{Cu}_{9} \mathrm{Al}_{4}$ and $\mathrm{CuAl}_{2}$ is a significant issue. One solution to this problem is the use of the suitable interlayer material. Use of interlayer material modifies the joint microstructure with the replacement of thick, brittle intermetallics by more ductile intermetallics in a thin layer or particle form. The present study is a preliminary investigation about joining of AA6082-O to pure copper joints with and without silver $(\mathrm{Ag})$ wire interlayer. Friction stir welded joints were characterized regarding optical microscopy, X-Ray Diffraction (XRD) analysis, microhardness measurement, tensile testing and Scanning Electron Microscopy (SEM) based fractography. The Al-Cu weld prepared using silver interlayer was stronger than without it. The higher strength of the weld with silver interlayer is attributed to the formation of a composite type of structure with intercalation of more ductile $\mathrm{Ag}_{2} \mathrm{Al}$ intermetallics along with dispersion of $\mathrm{Ag}$ particles in stir zone.
\end{abstract}

Keywords: Friction stir welding (FSW); $\mathrm{Al}$ to $\mathrm{Cu}$ welds; silver interlayer.

\section{Introduction}

Products involving dissimilar metal joints are required in various engineering sectors [1]. Dissimilar $\mathrm{Al}$ to $\mathrm{Cu}$ joints are having potential applications in process equipments such as refrigeration unit [2] and electronic industries [3]. However, due to variation in thermal and mechanical properties of base metals, several difficulties are encountered while joining dissimilar metals. Because of the possibility of formation of thick, brittle intermetallics, use of fusion welding processes is not recommended [4] for

\footnotetext{
*Corresponding author: Shailesh Pandya, s.pandya@med.svnit.ac.in
} 
welding different $\mathrm{Al}$ to $\mathrm{Cu}$ welds. In case of fusion welding techniques following critical issues are especially noteworthy: differences in melting points of base metals, differences in coefficients of thermal expansion of base metals, chances of solidification cracking, higher micro-residual stresses, the formation of brittle intermetallics, dilution of weld metal [4], and non-matching thermal conductivities of base metals.

Friction Stir Welding (FSW) has been developed by The Welding Institute (TWI) [5] in 1991. The FSW process was designed to join aluminum alloys [5, 6]. Being solidstate welding technique, several advantages are claimed for FSW process: absence of porosity, no fumes, and gases, no need of filler metals, the absence of melting and solidification related defects and low distortion [7]. Because of these reasons, FSW process has been emerged as a better option for welding dissimilar metals as compared to fusion welding processes. In friction stir welding, joining of metal takes place by frictional heating of base metals by a rotating non-consumable tool [5]. Under the axial pressure of the tool, the weld nugget is formed due to solid-state material flow resembling localized extrusion by the action of stirring pin of the tool. In friction stir welding process, the weld metal undergoes sizeable plastic deformation resulting in extremely fine grain structure [8].

Recently several studies [9-13] have been reported on microstructure and mechanical properties of different $\mathrm{Al}$ alloy to pure $\mathrm{Cu}$ joints prepared by friction stir welding (FSW) process. In general, solid-state intercalated vortex flow type of microstructure at the weld nugget [9-13] and formation of $\mathrm{Al}-\mathrm{Cu}$ intermetallics at the weld interface [10-13] is a common observation for friction stir welded dissimilar Al to $\mathrm{Cu}$ joints. Murr et al. investigated microstructural features of different copper to AA6061 FSWeldes [9]. Dynamically recrystallized, fine-grained intercalated solid-state vortex like or swirl-like structures were observed within stir zone. In appearance, these resemble non-linear dynamic fluid flow phenomena. It was concluded that the intercalation features within stir zone microstructure of dissimilar FSWeld is very similar to that obtained by mechanical alloying of metals. Notable hardness variations observed in vortex structure of stir zone was attributed to grain size variation and differences in thickness of intercalated layers. However, XRD analysis to identify intermetallics at the interface was not done. Galvão et al. [10] observed severe fluctuations in spindle torque during friction stir welding of dissimilar AA5083 to $\mathrm{Cu}$ sheets. These fluctuations were attributed to the high volume of intermetallics within weld. Tan et al. observed inhomogeneous hardness distribution within stir zone of dissimilar Aluminium alloy 5A02 to pure $\mathrm{Cu}$ weld made by friction stir welding (FSW) [11]. Higher hardness was noted at the $\mathrm{Al}$ to $\mathrm{Cu}$ interface. The inhomogeneous hardness distribution was attributed to nano-scaled intercalations of $\mathrm{Al}_{4} \mathrm{Cu}_{9}, \mathrm{Al}_{2} \mathrm{Cu}_{3}, \mathrm{Al}_{2} \mathrm{Cu}$ intermetallics in the lower stir zone. In the upper zone, a composite type structure with a dispersion of $\mathrm{Cu}$ particles was observed. Similar results were also reported by Sahu et al. [12] for dissimilar AA1050 to pure $\mathrm{Cu}$ weld made by friction stir welding. Formation of large amounts of $\mathrm{Al}_{4} \mathrm{Cu}_{9}, \mathrm{Al}_{2} \mathrm{Cu}_{3}, \mathrm{Al}_{2} \mathrm{Cu}$ intermetallics was noted in the lower stir zone because of higher cooling rate. Ouyang et al. [13] also observed the formation of $\mathrm{Al}_{4} \mathrm{Cu}_{9}, \mathrm{Al}_{2} \mathrm{Cu}$ and $\mathrm{CuAl}$ intermetallics in dissimilar friction stir welds of AA6061 and pure $\mathrm{Cu}$. Formation of brittle intermetallics during joining of $\mathrm{Al}$ to $\mathrm{Cu}$ sheets is a significant problem in achieving the reasonable strength of the weld [13].

Controlling the growth of intermetallics at the joint interface is essential for improving mechanical properties. Friction stir welding process parameters leading to 
low net heat input such as lower tool rotation speed and higher tool travel speed may be utilized to control the same. A critical process variable affecting the number of intermetallics formed is tool pin offset [14-15]. However, another efficient way to reduce the formation of intermetallics to achieve defect-free weld is the use of an interlayer between two parent metal sheets as suggested by Ouyang et al. [13]. Positive results have been reported for the use of copper interlayer in coating form for dissimilar friction stir welding of AA7075 and AA6061 alloys by J. Kandasamy et al. [16]. Interlayer if used may act as a barrier between $\mathrm{Al}$ and $\mathrm{Cu}$ sheets and minimize formation of brittle intermetallics of $\mathrm{Al}-\mathrm{Cu}$ system. However, with butt configuration, it may alter nature and form of intermetallics formed at the weld interface as interlayer material get mixed within stir zone in case of butt joint configuration.

As suggested by AWS [17], silver is preferred as the interlayer material for joining $\mathrm{Al}$ to $\mathrm{Cu}$ alloys based on results obtained with fusion welding techniques and rotary friction welding techniques. Use of $20 \mu \mathrm{m}$ thick silver interlayer [18] for joining dissimilar AA $6061 \mathrm{MMC}$ to AISI 304 stainless steel by rotary friction welding has also been reported. A few studies reported effects of Ag interlayer on microstructure and mechanical properties of different $\mathrm{Al}$ alloy to $\mathrm{Cu}$ alloy joints prepared by friction stir welding in butt configuration. The present study is a preliminary investigation about joining of different AA6082-O to pure copper joints using silver (Ag) interlayer in wire form. FSW joints are characterized in terms of microstructure, microhardness, tensile testing, fractography by scanning electron microscopy(SEM) and X-Ray Diffraction (XRD) analysis of joint interface.

\section{Experimental procedure}

For the investigation, 1.6 thick AA6082-O sheets and pure $\mathrm{Cu}$ sheets were cut into $150 \mathrm{~mm}$ x $100 \mathrm{~mm}$ pieces. Sheets were joined to each other along the $150 \mathrm{~mm}$ side by friction stir welding in butt configuration. A concave shoulder tool (Fig. 1) made from En31 alloy steel without any features on the shoulder surface was used.

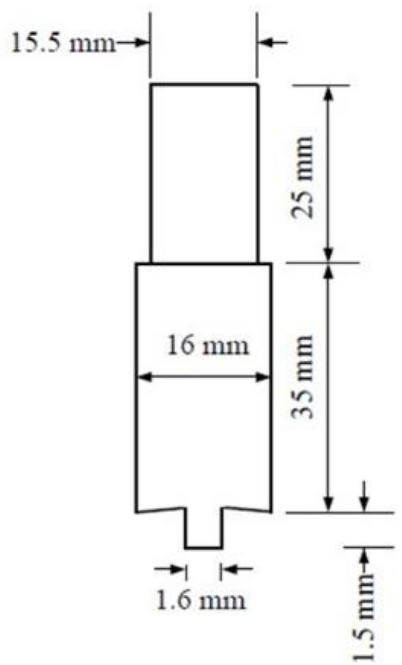


Fig. 1. Geometry and dimensions of the FSW tool.

The tool probe had standard cylindrical shape without threads on it. Tool shoulder diameter was $16 \mathrm{~mm}$ while the tool pin diameter was $1.6 \mathrm{~mm}$ with a pin length of $1.5 \mathrm{~mm}$. Friction stir welding was carried out on a modified conventional milling machine. Details of experiments are given in Table $1 . \mathrm{Cu}$ sheets were positioned on advancing side while AA6082-O sheets on retreating side. The Tool pin axis was shifted toward $\mathrm{Al}$ side in such a manner that tool pin peripheral surface just come into contact with a copper sheet during welding. Providing the tool pin offset toward AA6082-O reduces chances of tool pin wear. For the weld involving Ag interlayer $(\mathrm{Al} / \mathrm{Ag} / \mathrm{Cu})$, a pure silver wire having diameter $0.8 \mathrm{~mm}$ and length $150 \mathrm{~mm}$ was inserted between faying surfaces of the base metal sheets (Fig.2). A square groove of $0.8 \mathrm{~mm} \times$ $0.8 \mathrm{~mm}$ size was prepared by milling slots of $0.4 \mathrm{~mm}$ width and $0.8 \mathrm{~mm}$ depth on the faying edge of each base metal sheet. The $\mathrm{Ag}$ wire was inserted in the square groove. The approximate volume of $\mathrm{Ag}$ wire interlayer was $75.398 \mathrm{~mm}^{3}(\sim 0.79$ grams mass considering the density of $\mathrm{Ag}$ as $\left.10.497 \mathrm{gm} / \mathrm{cm}^{3}\right)$. Total volume swept by the tool shoulder beneath it (from stir zone + thermo-mechanically affected zone) in one weld run is approx. $3840 \mathrm{~mm}^{3}$ as tool shoulder diameter is $16 \mathrm{~mm}$, sheet thickness is $1.6 \mathrm{~mm}$, and weld run length is $150 \mathrm{~mm}$. Thus, making Ag amount added in the weld zone approx. $1.96 \%$ by volume to stir zone+ TMAZ volume beneath tool shoulder.

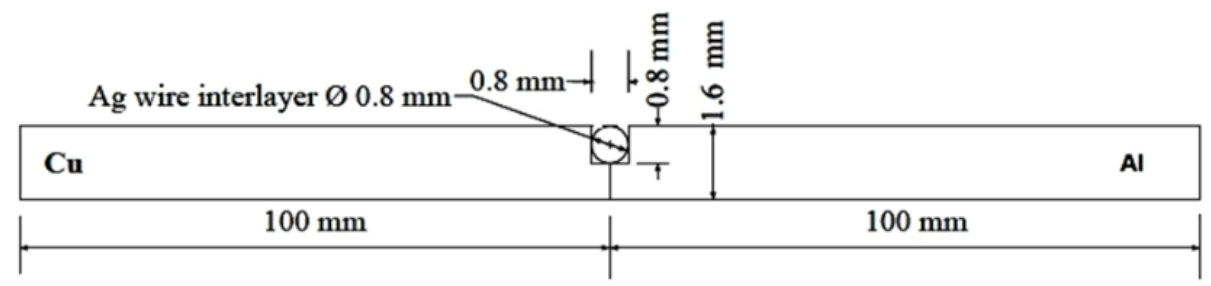

Fig. 2. Silver wire interlayer insertion in the square groove at the interface of base metal sheets.

After welding test, coupons were cut for various characterization. For microstructural characterization, specimens were prepared as per standard metallographic procedure. Finely polished specimens were etched. For Al side regions 4 ml HF mixed with $100 \mathrm{ml} \mathrm{H}_{2} \mathrm{O}$ solution was applied as an etchant. Pure $\mathrm{Cu}$ side was etched with a mixed solution of $4 \mathrm{ml}$ saturated $\mathrm{NaCl}$ solution, $2 \mathrm{~g}$ Potassium dichromate and $8 \mathrm{ml} \mathrm{H}_{2} \mathrm{SO}_{4}$ in $0.1 \mathrm{~L} \mathrm{H}_{2} \mathrm{O}$. Optical micrographs of various zones of cross-section of welds in transverse direction were taken. Vickers' microhardness measurements were carried out at the load of $200 \mathrm{~g}$ and dwell time period of 15 seconds. Micro-hardness indentations were carried out at weld interface and at intervals of $4 \mathrm{~mm}$ from weld interface on both (advancing side and retreating side) up to $20 \mathrm{~mm}$ across the welded joints. For tensile testing, the specimens were prepared as per ASTM-E08-2004. Average of two tensile tests were reported. The drawing of specimen and photograph of one sample is shown in Fig. 3 and Fig. 4 respectively. Tensile testing was carried out on $2 \mathrm{kN}$ capacity KCPL makes extensometer. A constant crosshead speed of $1 \mathrm{~mm} / \mathrm{min}$ was maintained during tests. After tensile testing, fractography of fractured tensile specimen was carried out using Scanning Electron Microscopy (SEM). 
XRD analysis was carried out on Bruker X-Ray diffractometer.

Table 1. Details of experiments.

\begin{tabular}{|c|c|c|c|c|}
\hline Sr. & FSWeld & Details & \multicolumn{2}{|c|}{ Common Process Variables } \\
\hline 1 & $\mathrm{Al} / \mathrm{Cu}$ & $\begin{array}{l}\text { Dissimilar AA6082-O } \\
\text { to pure } \mathrm{Cu} \text { without } \\
\text { interlayer }\end{array}$ & $\begin{array}{l}\text { Tool rotation speed: } \\
\text { Tool travel speed: } \\
\text { Tool tilt angle: } \\
\text { Plunge depth: }\end{array}$ & $\begin{array}{l}1000 \mathrm{rpm} \\
28 \mathrm{~mm} / \mathrm{min} \\
2.5^{\circ} \\
0.1 \mathrm{~mm}\end{array}$ \\
\hline 2 & $\mathrm{Al} / \mathrm{Ag} / \mathrm{Cu}$ & $\begin{array}{l}\text { Dissimilar AA6082-O } \\
\text { to pure } \mathrm{Cu} \text { with Silver } \\
\text { wire interlayer }\end{array}$ & $\begin{array}{l}\text { Tool offset } \\
\text { (toward AA6082-O } \\
\text { sheet) }\end{array}$ & $0.4 \mathrm{~mm}$ \\
\hline
\end{tabular}

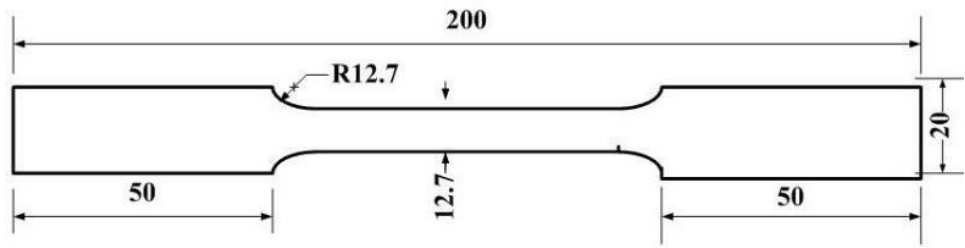

Fig. 3. Drawing of the tensile testing specimen, according to ASTM-E-08.

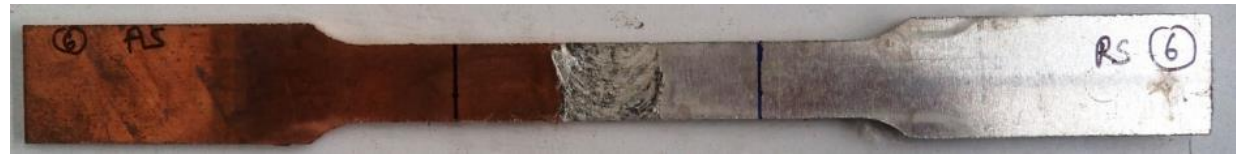

Fig. 4. Photograph of a prepared tensile testing specimen.

\section{Results and discussion}

The top surface appearance of both dissimilar welds is shown in Fig. 5. Visually inspected welds were found defect-free, except surface roughness defect. The macrostructure of cross-sections of both dissimilar welds is shown in Fig. 6. It is observed from a cross-section of welds that welds are defect-free. In dissimilar weld with Ag interlayer (Fig. 6 (b)), there is observed entrapped Al particle within top region of $\mathrm{Cu}$ side thermo-mechanically affected zone (TMAZ). In both dissimilar welds, slight thinning of the sheet is observed from the top due to plunging off the tool. Results of microstructural characterization are presented in Fig. 7 to Fig. 9. 


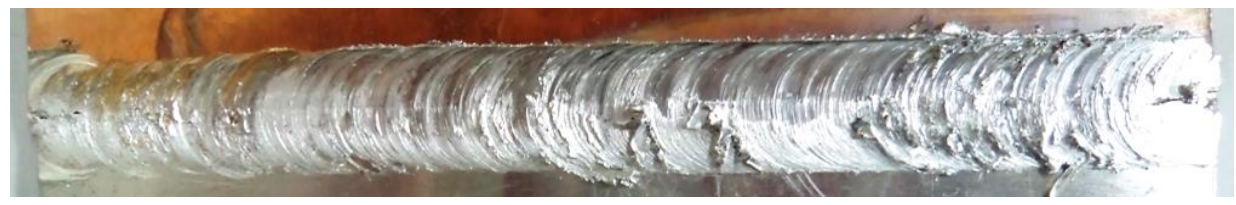

(a) $\mathrm{Al} / \mathrm{Cu}$

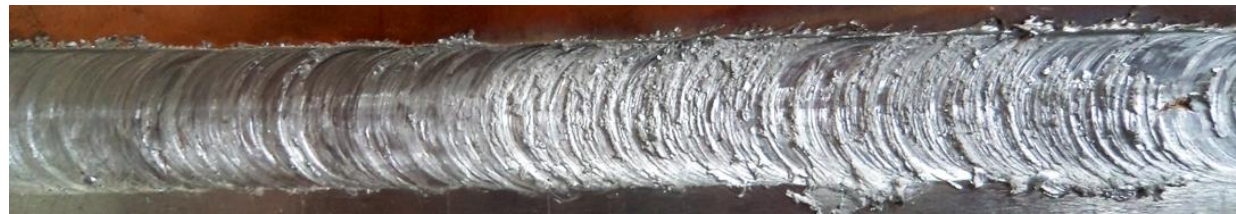

(b) $\mathrm{Al} / \mathrm{Ag} / \mathrm{Cu}$

Fig. 5. The top surface appearance of dissimilar welds.

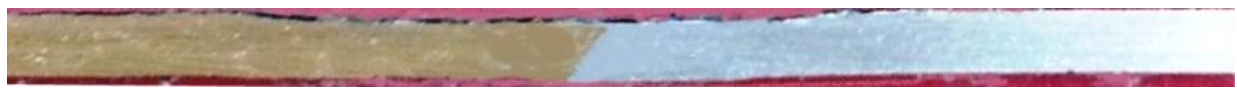

(a) $\mathrm{Al} / \mathrm{Cu}$

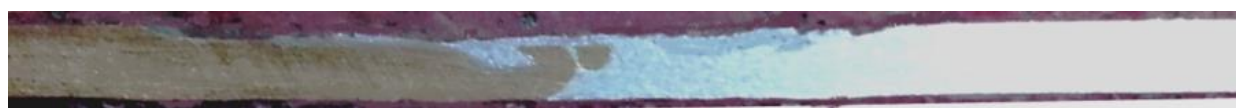

(b) $\mathrm{Al} / \mathrm{Ag} / \mathrm{Cu}$

Fig. 6. The macrostructure of a cross-section of dissimilar welds (Al on retreating side and $\mathrm{Cu}$ on advancing side).

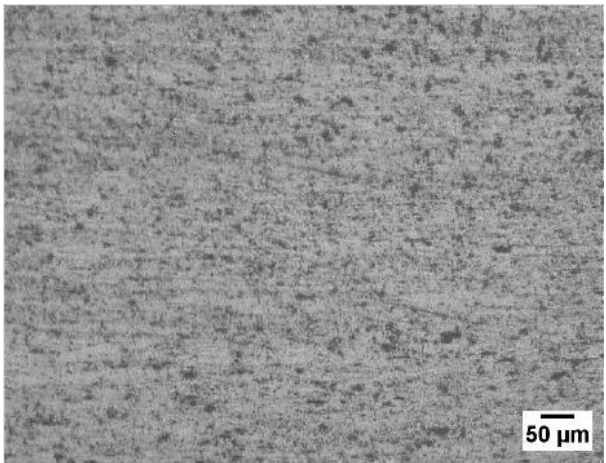

(a) Base metal AA6082-O

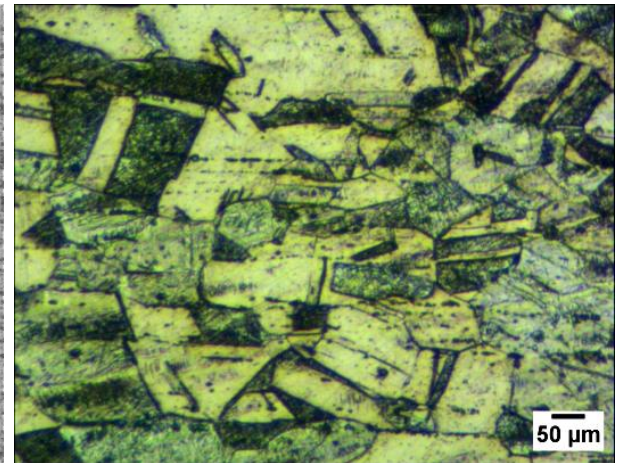

(b) Base metal pure Copper

Fig. 7. The microstructure of base metal AA6082-O and pure Cu.

The microstructure of unprocessed work material AA6082-O (Fig. 7 (a)) consists of fine grains. The microstructure of pure $\mathrm{Cu}$ consists of coarse $\mathrm{Cu}$ grains with twins. Optical micrographs of $\mathrm{Al} / \mathrm{Cu}$ weld are shown in Fig. 8. Coarse grains are observed in heat affected zone (HAZ) region on advancing side. However, reduction in grain size in $\mathrm{Cu}$ side of stir zone is observed. Typical onion ring pattern and dynamically recrystallized grain structure can be seen near weld interface (Fig. 8 (c)). HAZ on the 
retreating side is having coarse grains as compared to parent metal AA6082-O. However, grain coarsening is in less extent indicating lower peak temperature reached during friction stir welding (Fig. 8 (d)). Fine precipitates are also observed which require further investigation in terms of X-ray diffraction(XRD) analysis. From optical micrographs of $\mathrm{Al} / \mathrm{Ag} / \mathrm{Cu}$ weld (Fig. 9), it can be observed that microstructure of heat affected zone(HAZ) on both advancing and retreating side is very similar to that of $\mathrm{Al} / \mathrm{Cu}$ weld. However, within stir zone of $\mathrm{Al} / \mathrm{Ag} / \mathrm{Cu}$ weld, intercalated layers (Fig. 9 (c)) of $\mathrm{Al}, \mathrm{Cu}, \mathrm{Ag}$, and their intermetallics are observed. Within stir zone, near weld interface (on $\mathrm{Al}$ side) lustrous particles dispersed within $\mathrm{Al}$ matrix are observed (Fig. 9 (d)), which may be of Silver (Ag) or compounds of $\mathrm{Ag}, \mathrm{Al}$ and $\mathrm{Cu}$. However, for confirmation investigation such as X-ray diffraction(XRD) analysis is required. It can be concluded that with the inclusion of $\mathrm{Ag}$ interlayer there is the formation of a composite type of structure in stir zone of $\mathrm{Al} / \mathrm{Ag} / \mathrm{Cu}$ weld.

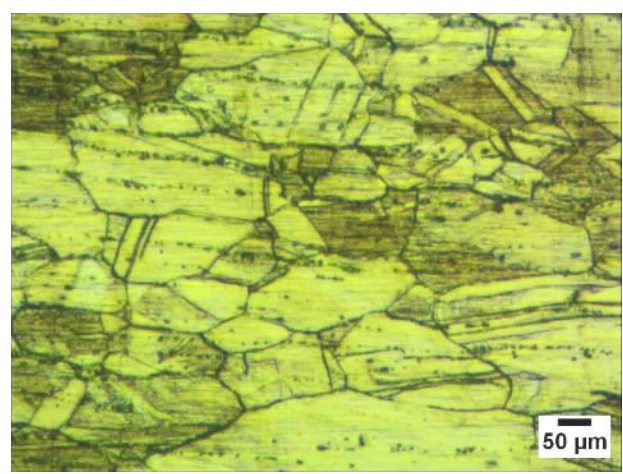

(a) Heat affected zone (Advancing side)

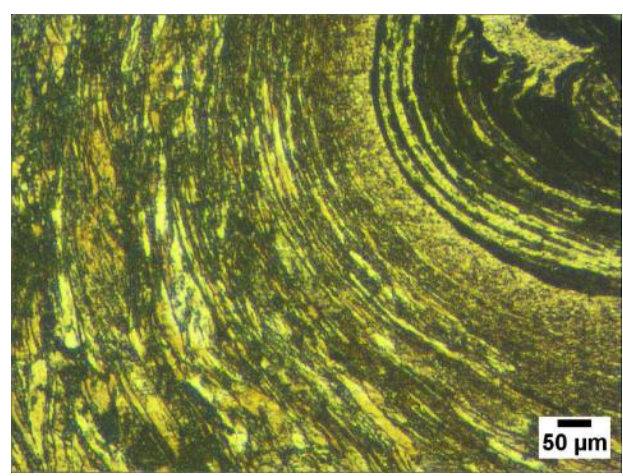

(c) Intercalated layers near weld interface

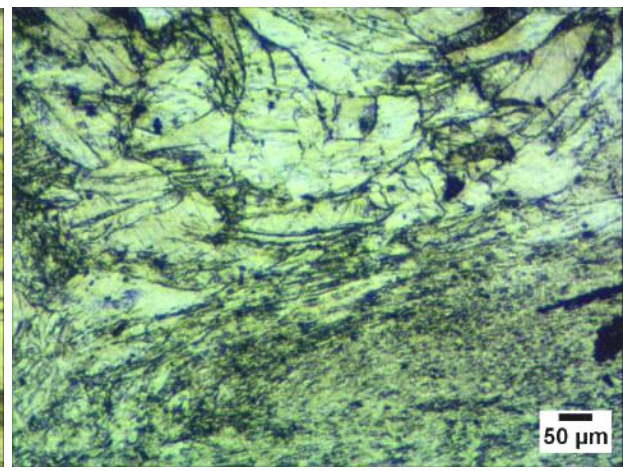

(b) Stir zone (Advancing side)

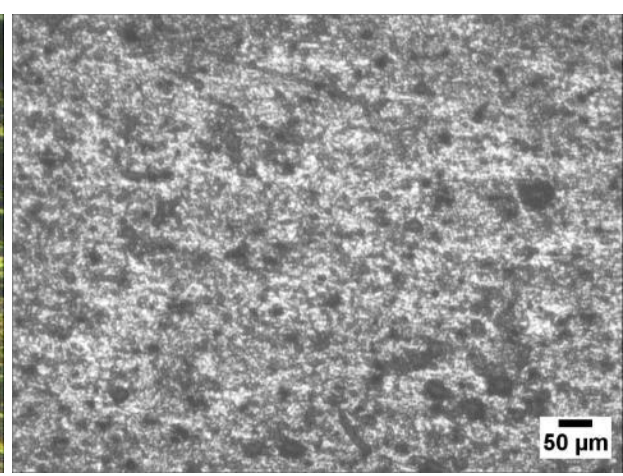

(d) Heat affected zone (Retreating side)

Fig.8 Optical micrographs of various regions of Al/Cu weld 


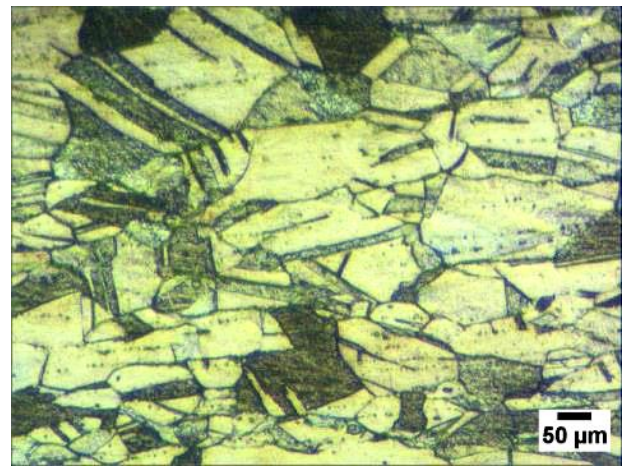

(a) Heat affected zone (Advancing side)

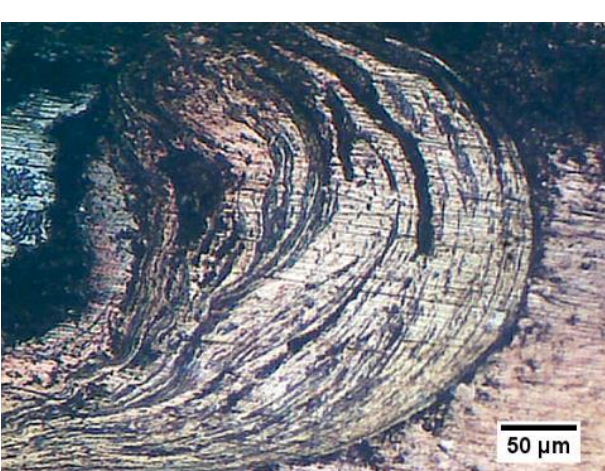

(c) Intercalation within stir zone

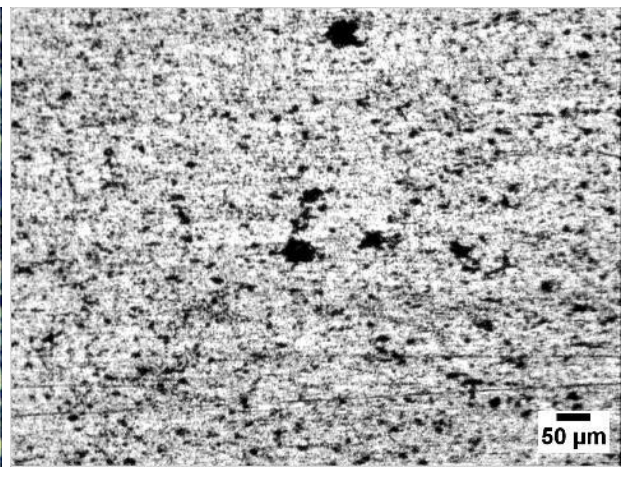

(d) Heat affected zone (Retreating side)

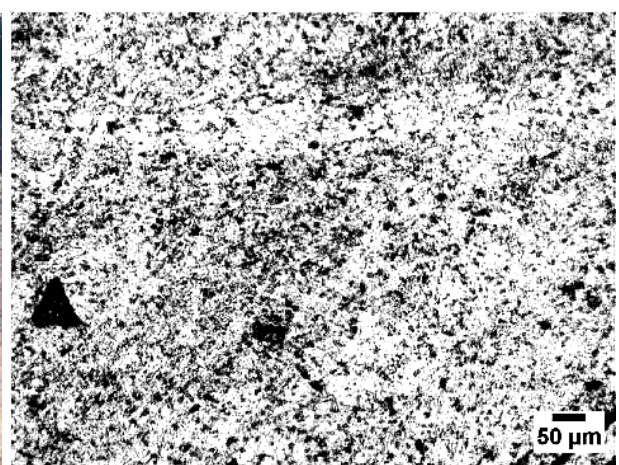

(d) Ag dispersion on Al side of weld interface

Fig. 9. Optical micrographs of various zones of $\mathrm{Al} / \mathrm{Ag} / \mathrm{Cu}$ weld.

XRD analysis results are plotted in Fig. 10. In case of XRD pattern for $\mathrm{Al}$ to $\mathrm{Cu}$ dissimilar welds without silver addition, there can be seen peaks for $\mathrm{Al}$ and $\mathrm{Cu}$. Besides, there is also observed the presence of an intermetallic of $\mathrm{Al}-\mathrm{Cu}$ system - $\mathrm{Cu}_{9} \mathrm{Al}_{4}$. However, when Silver wire interlayer is used, the formation of $\mathrm{Cu}_{9} \mathrm{Al}_{4}$ intermetallics suppressed. Instead, $\mathrm{Ag}_{2} \mathrm{Al}$ intermetallic of $\mathrm{Ag}-\mathrm{Al}$ system is formed along with pure $\mathrm{Ag}$ particles. Further, intermetallic $\mathrm{Ag}_{2} \mathrm{Al}$ is dispersed as intercalation with $\mathrm{Al}, \mathrm{Cu}$ and $\mathrm{Ag}$ layers as well dispersed with $\mathrm{Al}$ matrix forming a composite type of structure when $\mathrm{Ag}$ interlayer is inserted between AA6082 and pure $\mathrm{Cu}$ as revealed by optical microscopy. 


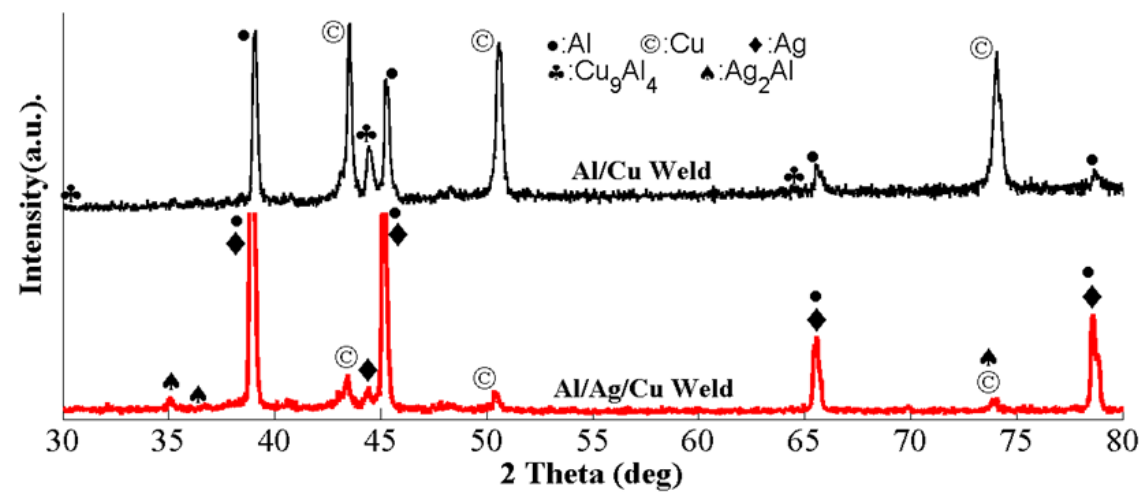

Fig. 10. XRD analysis of dissimilar welds.

Micro-hardness indentations were carried out at weld interface and at intervals of $4 \mathrm{~mm}$ from weld interface on both (advancing side and retreating side) up to $20 \mathrm{~mm}$. Results of the same (HV0.2) are tabulated in Table 2.

Table 2. Micro-hardness distribution for FSwelds (HVO.2).

\begin{tabular}{lrrrrrrrrrrr}
\hline Weld & \multicolumn{10}{c}{ Distance from weld interface $(\mathrm{mm})$} \\
\cline { 2 - 12 } & -20 & -16 & -12 & -8 & -4 & 0 & 4 & 8 & 12 & 16 & 20 \\
\cline { 2 - 11 } $\mathrm{Al} / \mathrm{Cu}$ & 84 & 89 & 88 & 90 & 88 & 90 & 27 & 32 & 38 & 40 & 41 \\
$\mathrm{Al} / \mathrm{Ag} / \mathrm{Cu}$ & 84 & 89 & 88 & 76 & 90 & 101 & 25 & 29 & 40 & 43 & 42 \\
\hline
\end{tabular}

Here distance with 'minus' (-) sign indicates advancing side (AS) and with plus indicates retreating side (RS), while ' 0 ' indicates weld interface. The same is also plotted in Fig. 11.

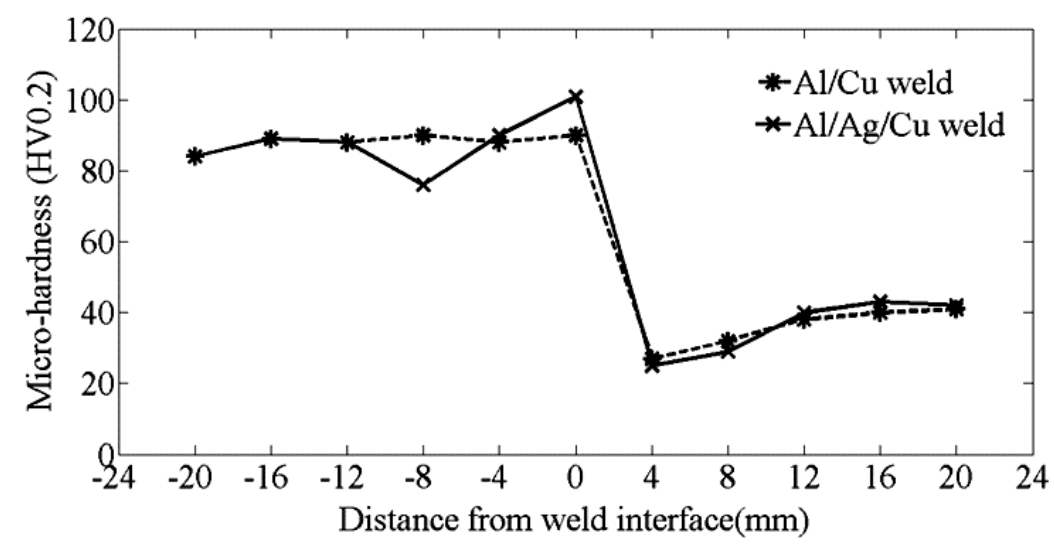

Fig. 11. Vickers' micro-hardness distribution across the weld.

Micro-hardness of base metal AA6082-O was measured $40 \mathrm{HV} 0.2$ while that of pure $\mathrm{Cu}$ was observed $86 \mathrm{HV} 0.2$. For $\mathrm{Al} / \mathrm{Cu}$ welds, it can be seen that there is observed slightly higher ( $90 \mathrm{HV} 0.2$ ) values up to $8 \mathrm{~mm}$ on $\mathrm{AS}(\mathrm{Cu}$ side) from the interface this 
may be due to a significant amount of intermetallics and strengthening due to continuous dynamic recrystallization. Continuous dynamic recrystallization takes place due to the unusually high amount of plastic deformation during the friction stir welding process. Due to dynamic recrystallization, grain refinement takes place resulting in fine grain structure. It is well established that materials with fine grain structure are stronger and harder as per grain size strengthening mechanism. For $\mathrm{Al} / \mathrm{Ag} / \mathrm{Cu}$ weld, there are observed a drastic and notable rise in the microhardness of the interface (up to 101 $\mathrm{HV}$ 0.2). In a recent study by Wang et al. [19], the hardness of $\mathrm{Ag}_{2} \mathrm{Al}$ intermetallic formed in diffusion bonded joint prepared at a temperature of $470{ }^{\circ} \mathrm{C}$ was observed $176.5 \mathrm{HV}(\sim 1.73 \mathrm{GPa})$. It should be noted that microhardness of $\mathrm{Ag}_{2} \mathrm{Al}$ is notably lower than microhardness of $\mathrm{Cu}_{9} \mathrm{Al}_{4}$ that is $5.20 \mathrm{GPa}$ [20], even then for the joint with $\mathrm{Ag}$ interlayer, average microhardness is higher than the joint without an interlayer. It could be explained based on the difference in size, amount and form of both intermetallics $\left(\mathrm{Ag}_{2} \mathrm{Al}\right.$ vs. $\left.\mathrm{Cu}_{9} \mathrm{Al}_{4}\right)$ and strengthening by dispersion of $\mathrm{Ag}$ particles within stir zone as confirmed by optical microscopy (Fig. 8 and Fig. 9) and XRD analysis (Fig. 10). There is also the contribution of increased hardness because of grain refinement due to dynamic recrystallization. In this way strengthening of the $\mathrm{Al} / \mathrm{Ag} / \mathrm{Cu}$ stir zone could be attributed to the formation of composite type of structure with intercalation of $\mathrm{Al}, \mathrm{Cu}$, $\mathrm{Ag}$ and $\mathrm{Ag}_{2} \mathrm{Al}$ intermetallics particles and refined grain structure within weld zone.

Tensile testing results are summarized in Table 3. All tensile specimens were broken from stir zone. Results of transverse tensile tests indicate that there is a rise in tensile strength of dissimilar welds when silver wire interlayer is used. The results are in line with results of micro-hardness distribution and indicate that use of $\mathrm{Ag}$ interlayer improves properties of FSWelded dissimilar $\mathrm{Al}$ to $\mathrm{Cu}$ joints. The higher tensile strength of the dissimilar weld made with $\mathrm{Ag}$ interlayer can be attributed to the suppressed growth of brittle intermetallic $\mathrm{Cu}_{9} \mathrm{Al}_{4}$ and formation of more ductile $\mathrm{Ag}_{2} \mathrm{Al}$ intermetallics along with a composite structure formed by intercalation of $\mathrm{Ag}_{2} \mathrm{Al}$ with a layer of work material AA6082-O and pure $\mathrm{Cu}$ and strengthening by dispersion of $\mathrm{Ag}$ particles. Very lower yield strength observed for $\mathrm{Al} / \mathrm{Cu}$ weld is another indication for the presence of brittle intermetallic at the $\mathrm{Al} / \mathrm{Cu}$ weld interface. However, notable improvement has been observed in yield strength of $\mathrm{Al} / \mathrm{Ag} / \mathrm{Cu}$ weld. This may be attributed to strengthening by $\mathrm{Ag}$ particles. On the other side, \% elongation of both welds was noted nearly same.

Table 3. Results of the tensile test.

\begin{tabular}{lccc}
\hline Weld & $\begin{array}{c}\text { Ultimate Tensile } \\
\text { Strength (MPa) }\end{array}$ & $\begin{array}{c}\text { Yield Strength } \\
(\mathrm{MPa})\end{array}$ & $\begin{array}{c}\text { Elongation } \\
(\%)\end{array}$ \\
\hline $\mathrm{Al} / \mathrm{Cu}$ & 37.8 & 11.1 & 2.70 \\
$\mathrm{Al} / \mathrm{Ag} / \mathrm{Cu}$ & 64.2 & 36.7 & 2.56 \\
\hline
\end{tabular}




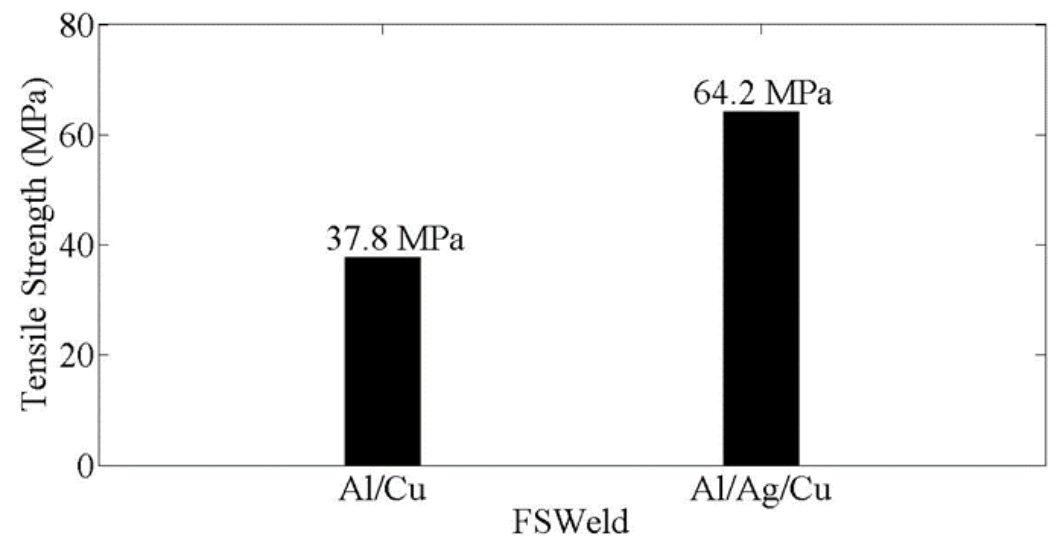

Fig. 12. Comparison of the tensile strength of dissimilar welds.

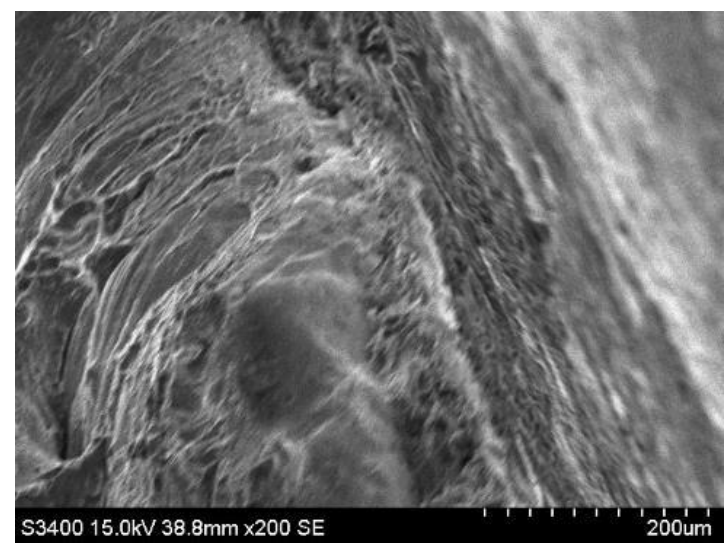

(a) Al/Cu weld

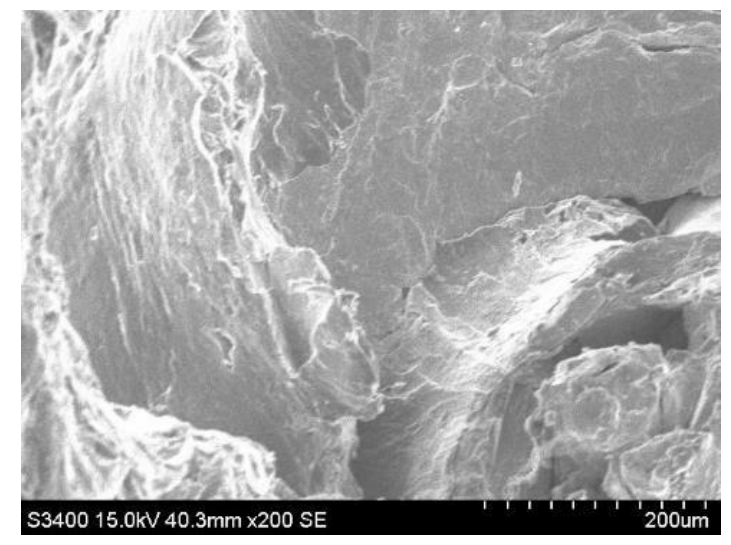

(b) $\mathrm{Al} / \mathrm{Ag} / \mathrm{Cu}$ weld

Fig. 13. SEM fractography of fractured tensile specimens for dissimilar joints. 
SEM fractography of tensile specimen for $\mathrm{Al} / \mathrm{Cu}$ dissimilar joint without silver layer addition is shown in Fig. 13 (a). Two regions are observed: flat surface and fine dimples. Dimples indicate that the dominant mode of failure is a ductile fracture. Flat facets indicate that there is some contribution of brittle fracture. Here cone-shaped equiaxed dimples are observed which indicates that the failure is due to simple tensile loading. SEM fractography for dissimilar $\mathrm{Al}$ alloy to pure $\mathrm{Cu}$ joint with silver interlayer is shown in Fig. 13 (b). Here the presence of dimples again indicates purely ductile fracture mode. However, it can be seen that there are dimples with an equiaxed appearance as well as dimples having elongated parabolic shapes can be seen. This indicates shearing failure + tensile fracture. Dimples are slightly deeper also. The presence of $\mathrm{Ag}$ interlayer in $\mathrm{Al}$ to $\mathrm{Cu}$ stir welded joints has resulted in a decrease in the size of dimples; Here other factors such as grain refinement, strain hardening by dislocation movement may also contributed to increased strength.

\section{Conclusion}

Following conclusions can be drawn from the present study: (1) A preliminary investigation comparing joint microstructure and properties of dissimilar AA6082-O to pure $\mathrm{Cu}$ joints made without $\mathrm{Ag}$ interlayer and with $\mathrm{Ag}$ interlayer in wire form is carried out. (2) For dissimilar AA6082-O to pure $\mathrm{Cu}$ joints with $\mathrm{Ag}$ interlayer, an intercalated microstructure with dynamically recrystallized stir zone was observed with a dispersion of lustrous Ag particles. (3) There is observed higher interfacial microhardness (HV0.2) value in the weld prepared with $\mathrm{Ag}$ interlayer as compared to the weld without $\mathrm{Ag}$ interlayer. Similar results are observed for Ultimate Tensile Strength (UTS). (4) XRD analysis revealed that at the weld interface of welds made without silver interlayer there is observed $\mathrm{Cu}_{9} \mathrm{Al}_{4}$ intermetallic. However, silver addition in the dissimilar joint suppressed formation of $\mathrm{Cu}_{9} \mathrm{Al}_{4}$, and there is observed $\mathrm{Ag}_{2} \mathrm{Al}$ intermetallic formation in addition to Ag particles. (5) The higher tensile strength of the dissimilar weld made with $\mathrm{Ag}$ interlayer can be attributed to the suppressed growth of brittle intermetallic $\mathrm{Cu}_{9} \mathrm{Al}_{4}$ and formation of more ductile $\mathrm{Ag}_{2} \mathrm{Al}$ intermetallic forming a composite structure. Intercalated $\mathrm{Ag}_{2} \mathrm{Al}$ intermetallics acting as reinforcement as well as in the form of intercalation with layers of work material AA6082-O and pure $\mathrm{Cu}$ along with dispersed Ag particles improved the strength of the weld.

\section{References}

[1] C. H. Muralimohan, S. Haribabu, Y. H. Reddy, V. Muthupandi, K. Sivaprasad: Procedia Mater Sci, 5 (2014) 1107-1113.

[2] B. Mvola, P. Kah, J. Martikainen: Int J Mech Mater Eng, 9 (2014) 1-9.

[3] N. Kumar, W. Yuan, R. S. Mishra, Friction stir welding of dissimilar alloys and materials, 1st Ed., Butterworth-Heinemann, Oxford, UK, 2015, 85.

[4] S Imaizumi: Weld Int, 10 (1996) 593-604.

[5] W. M. Thomas, E. D. Nicholas, J. C. Needham, M. G. Murch, P. Templesmith, C. J. Dawes, G.B. Pat Appl No. 9125978.8, 1991.

[6] Dawes C J \& Thomas W M: TWI Bull, 6 (1995) 124.

[7] E.T. Akinlabi: J Mater Eng Perform, 21 (7) (2012) 1514-1519.

[8] P.B. Prangnell and C.P. Heason: Acta Mater, 53 (2005) 3179-3192.

[9] L.E. Murr, Y. Li, R. D. Flores, E. A. Trillo, J. C. McClure: Mater Res Innovations, 2 (1998) 150-163. 
[10] I Galvao, C Leitao, A Loureiro, D M Rodrigues: Mater Des, 42 (2012) 259-264.

[11] C.W. Tan, Z.G. Jiang, L.Q. Li, Y.B. Chen, X.Y. Chen: Mater and Des, 51 (2013) 466-473.

[12] P K Sahu, S. Pal, S K Pal, R. Jain: J Mater Process Technol, 235 (2016) 55-67.

[13] J Ouyang, E Yarrapareddy, R Kovacevic: J Mater Process Technol, 172 (2006) $110-122$.

[14] M. N. Avettand-Fenoel, R. Taillard, G. Ji, D. Goran: Metall Mater Trans A, 43 (2012) 4655-4666.

[15] I. Galvao, A. Loureiro, D. Verdera, D. Gesto, D. M. Rodrigues: Metall Mater Trans A, 43A (2012) 5096-5105.

[16] J. Kandasamy, M. M. Hussain, S. Rajesham: Mater Manuf Processes, 27 (2012) 1429-1436.

[17] C. Weisman, W H Kearna (Editors), AWS Welding Handbook Vol.4, Metals \& their Weldability, 7th Ed., American Welding Society, Michigan, 1982, 536.

[18] C. Maldonado, A. M. Flores, L. B. Gomez, A. Ruiz, I. Alfonso, J. A. Ascencio: Rev Me Fis, S 55 (1) (2009) 130-134.

[19] Y. Wang, G. Luo, L. Li, Q. Shen, L. Zhang: J Mater Sci, 49 (2014) 7298-7308.

[20] M H M Kouters, G H M Gubbels, O D. S. Ferreira: Microelectron Reliab, 53 (2013) 1068-1075.

\section{(c) (i) Creative Commons License}

This work is licensed under a Creative Commons Attribution 4.0 International License. 